\title{
Media Gambar Untuk Meningkatkan Proses Dan Hasil Belajar Siswa Pada Pembelajaran Pkn
}

\author{
Yul Eferi
}

SDN 18 Batang Anai Kabupaten Padang Pariaman

\begin{abstract}
Learning of civics subject at 3rd grade of SDN 18 Batang Anai Kabupaten Padang Pariaman did not optimize the media. It caused the learning process and achievement of students being low. This study is a classroom action research with two cycles aimed to improve students' learning process and achievement by implementing media of picture. Data were collected through observastion and test. Indicators of learning proces improvement: in cycle I, score of students' creativity is $40 \%$, students' motivation is $32 \%$, students' participation in answering question is $35 \%$; in cycle II, score of students' creativity is $86 \%$, students' motivation is $92 \%$, and atudents' participation in answering question is $89 \%$. Mean of students' test score in cycle I is 6.4 and in cycle II is 8.0. Hence, media of picture can improve students' learning process and achievement in civics subjects.
\end{abstract}

Kata Kunci: learning achievement, learning process, civics subject, picture media

\footnotetext{
(i) This is an open access article distributed under the Creative Commons Attribution License, which permits unrestricted use, distribution, and reproduction in any medium, provided the original work is properly cited. (C2017 by author and Indonesian Institute for Counseling, Education and Therapy (IICET).
}

\section{PENDAHULUAN}

Depdiknas (2007) mengungkapkan bahwa Pendidikan Kewarganegaraan merupakan mata pelajaran sosial yang bertujuan untuk membentuk atau membina warga negara yang baik, yaitu warga negara yang baru, mau dan mampu berbuat baik. Di samping itu, menurut Depdiknas (2006) bahwa Pendidikan Kewarganegaraan merupakan mata pelajaran yang memfokuskan pada pembentukan warga negara yang memahami dan mampu melaksanakan hak-hak dan kewajiban untuk menjadi warga negara yang cerdas, terampil dan memiliki karakter seperti yang diamanatkan oleh Pancasila dan UUD 1945. Menurut Depdiknas (2006), PKn bertujuan agar siswa memiliki kemampuan sebagai berikut: 1) Berfikir secara kritis, rasional, dan kreatif dalam menanggapi isu kewarganegaraan. 2) Berpartisipasi secara aktif dan bertanggung jawab, dan bertindak secara cerdas dalam kegiatan bermasyarakat, berbangsa, dan bernegara serta anti terhadap korupsi. 3) Berkembang secara positif dan demokratis untuk membentuk diri berdasarkan karakter-karakter masyarakat Indonesia agar dapat hidup bersama dengan bangsa-bangsa lainnya. 4) Berinteraksi dengan bangsa-bangsa lain dalam percaturan dunia secara langsung atau tidak langsung dengan memanfaatkan teknologi informasi dan komunikasi.

Dalam proses pembelajaran, penggunaan media gambar mempunyai arti yang cukup penting karena media merupakan alat untuk membantu siswa memahami pembelajaran dengan mudah. Kerumitan materi pembelajaran yang akan disampaikan kepada siswa dapat disederhanakan dengan bantuan media. Materi pembelajaran yang abstrak dapat disajikan melalui media. Mengingat pentingnya media pembelajaran, seorang guru dituntut agar mampu menggunakan media dalam proses pembelajaran, sehingga hal tersebut dapat meningkatkan motivasi dan keaktifan siswa dalam proses pembelajaran Pendidikan Kewarganegaraan (PKn) di sekolah dasar (SD). Untuk mencapai 
sasaran dan target di atas, guru seharusnya mampu melaksanakan penataan alat, bahan dan media agar mudah digunakan oleh siswa.

Berdasarkan pengalaman peneliti mengajar di III SDN 18 Batang Anai bahwa hasil belajar PKn siswa hanya mencapai rata-rata 5,9 (terdapat pada lampiran 7); dengan kata lain nilai yang dicapai siswa di bawah nilai Standar Ketuntasan Belajar Minimum sebanyak 65\%. Seharusnya guru dalam penyajian pembelajaran PKn tentang materi perilaku yang mencerminkan harga diri dan tidak mencerminkan perilaku harga diri, menggunakan media gambar agar siswa dapat mengerti dengan apa yang dijelaskan guru serta proses pembelajaran menarik. Penggunaan media gambar merupakan alat bantu bagi guru untuk mempermudah siswa memahami konsep-konsep yang akan dipelajari dalam berbagai materi pembelajaran. Untuk meningkatkan hasil belajar siswa dalam pembelajaran PKn, seorang guru bukan hanya mengerti, tetapi dapat memilih media yang sesuai dengan materi pembelajaran. Salah satu media yang dapat digunakan adalah media gambar. Dari fenomena yang diperoleh di lapangan, maka peneliti menganggapi bahwa hal ini perlu dikaji. Dalam hal ini perlu dikembangkan suatu pembelajaran yang bermakna, sehingga tercipta lingkungan yang alamiah yang dekat dengan alam nyata. Media gambar dalam proses pembelajaran PKn di SD dapat mengarahkan siswa untuk membedakan perilaku yang mencerminkan harga diri dan tidak mencerminkan harga diri, sehingga siswa akan lebih kreatif dan termotivasi dalam belajar.

Salah satu media yang sesuai dengan materi pembelajaran PKn SD adalah media gambar. Media ini termasuk salah satu jenis visual yang bermanfaat untuk mengkongkritkan hal-hal yang bersifat abstrak. Gambar atau foto juga dapat menggambarkan perilaku manusia. Guru dalam kegiatan pembelajaran berperan sebagai fasilitator, yang bertugas mendidik, membimbing dan menciptakan situasi yang memungkinkan terjadinya proses pembelajaran yang efektif. Supaya tercipta pembelajaran PKn yang berkualitas, seorang guru harus: a) menguasai bahan ajar; b) mengelola program belajar mengajar; c) mengelola kelas; d) menggunakan madia dan sumber belajar; e) mengelola interaksi belajar mengajar; f) menilai prestasi peserta didik. (Refinaldi, 2010). Media gambar sangat penting digunakan sebagai usaha memperjelas pengertian kepada siswa. Media merupakan alat atau sarana penunjang dalam keberhasilan proses pembelajaran. Gambar merupakan salah satu jenis media pendidikan berupa reproduksi asli dalam dua dimensi yang memungkinkan terjadinya komunikasi. Media gambar adalah sarana yang dapat membantu proses belajar mengajar; sarana itu bisa mencapai proses pembelajaran siswa dan dapat membantu proses pembelajaran menarik dan relatif lebih murah. Media gambar ini juga dapat membantu siswa dan guru untuk menciptakan proses pembelajaran yang lebih baik serta dipakai dengan tepat.

\section{METODE}

Jenis penelitian yang peneliti lakukan adalah penelitian tindakan kelas (PTK). Pendekatan ini berkenaan dengan perbaikan atau peningkatan hasil pembelajaran pada suatu kelas. Menurut Kemmis dan Mc Taggart dalam Ritawati (2007:69), proses penelitian tindakan merupakan daur ulang atau siklus penelitian yang dimulai dari aspek mengembangkan perencanaan melakukan tindakan sesuai rencana, melakukan observasi terhadap tindakan dan melakukan refleksi yaitu perenungan terhadap perencanaan. Kegiatan tindakan dan kesuksesan hasil yang diperoleh sesuai dengan prinsip umum penelitian tindakan, setiap tahap dan siklus selalu secara pertisipatoris dan kolaboratif antara peneliti dan praktisi (guru dan kepala sekolah). Penelitian ini diadakan di SDN 18 Batang Anai Kabupaten Padang Pariaman.

Penelitian ini dilakukan pada kelas III. Faktor yang melandasi pengambilan lokasi ini adalah pertama kesediaan kepala sekolah untuk meningkatkan hasil belajar siswa, kedua masih adanya sejumlah masalah, kendala yang dihadapi oleh peneliti di sekolah dalam pelaksanaan program sekolah khususnya dalam pembelajaran PKn. Subjek dalam penelitian ini adalah siswa kelas III SDN 18 Batang Anai dengan jumlah siswa 35 orang. Penelitian ini dikatakan berhasil apabila siswa telah mencapai ketuntasan belajar $65 \%$. Penelitian ini akan dilaksanakan melalui beberapa tahapan yaitu: (1) tahap perencanaan; (2) tahap tindakan dan observasi; (3) analisis data; (4) refleksi. Instrumen yang dilakukan dalam kegiatan penelitian tindakan kelas ini adalah: (1) Pedoman observasi untuk mengecek kegiatan yang dilakukan berdasarkan indikator dan sub indikator yang 
telah ditentukan sebelumnya. Aspek yang akan diamati adalah: kreativitas, motivasi, dan partisipasi siswa; (2) Lembar tes untuk siswa untuk mengetahui keberhasilan dan pendidikan yang telah diberikan.

\section{HASIL}

\section{Deskripsi Siklus I}

\section{Perencanaan}

Pada tahap ini penggunaan media gambar dalam pembelajaran menampilkan perilaku yang mencerminkan harga diri ditampilkan dalam bentuk rencana pelaksanaan pembelajaran (RPP). Rencana ini disusun secara kolaboratif antara peneliti dengan kepala sekolah, karena pengamatan dilakukan oleh kepala sekolah tersebut.

\section{Pelaksanaan}

Indikator yang ingin dicapai dalam pembelajaran adalah: 1) Menceritakan gambar tentang perilaku yang mencerminkan harga diri dan yang tidak mencerminkan harga diri dengan bahasa sendiri; 2) Membedakan tindakan perilaku yang mencerminkan harga diri dan yang tidak mencerminkan harga diri; 3) Mendemonstrasikan tentang perilaku yang mencerminkan harga diri dan yang tidak mencerminkan harga diri.

\section{Pengamatan}

Pengamatan terhadap tindakan penggunaan media gambar pada pembelajaran PKn di kelas III SDN 18 Batang Anai dilakukan bersama dengan pelaksanaan tindakan. Pengamatan dilakukan secara terus menerus mulai dari pelaksanaan tindakan sampai tindakan berakhir. Pengamatan yang dilakukan pada satu tindakan dapat mempengaruhi penyusunan tindakan selanjutnya. Pada saat peneliti memajangkan gambar, siswa tampak antusias salam mengamati gambar. Hal ini disebabkan gambar yang dipajang guru sudah menarik sehingga menimbulkan rasa ingin tahu siswa tentang gambar. Pada saat siswa diminta untuk mengomentari gambar, hanya sebagian kecil siswa yang mau mengomentari. Hal ini disebabkan ada bagian gambar yang kurang jelas oleh siswa karena ukurannya kecil dan menimbulkan pertanyaan yang mengakibatkan keributan.

Pada saat siswa mengomentari gambar di depan kelas, masih banyak siswa yang meribut, ini dikarenakan peneliti kurang mengontrol siswa pada saat proses pembelajaran. Pada saat siswa diminta menanggapi komentar teman, hanya sebagian kecil siswa yang bersedia, hal ini disebabkan kurangnya motivasi dan penguatan oleh peneliti pada saat proses pembelajaran berlangsung. Berdasarkan catatan lapangan maka masih ditemukan pula hal-hal sebagai berikut. Pertama, tidak menyiapkan kelas dengan baik atau manajemen kurang baik. Kedua, hanya sebagian kecil siswa yang bersedia mengomentari media gambar itu dikarenakan ada sebagian gambar yang kurang jelas dan menimbulkan keraguan dan pertanyaan bagi siswa. Ketiga, kurangnya motivasi dari guru. Keempat, guru kurang membimbing siswa pada waktu siswa menyelesaikan soal, karena masih ada beberapa orang siswa yang daya bacanya masih rendah, sehingga ada siswa yang melihat kekiri dan kekanan, mencontek punya teman karena kesulitan waktu menyelesaikan soal.

Tabel 1. Proses Pembelajaran Siswa pada Siklus I

\begin{tabular}{lcc}
\hline \multicolumn{1}{c}{ Aspek yang Diamati } & Jumlah Siswa & Persen \\
\hline Kreativitas siswa dalam mengomentari gambar & 14 & $40 \%$ \\
Motivasi siswa dalam menanggapi komentar teman & 11 & $32 \%$ \\
Menjawab pertanyaan guru & 12 & $35 \%$ \\
\hline
\end{tabular}

Berdasarkan tabel di atas dapat disimpulkan hasil dari proses pembelajaran PKn tentang mencerminkan harga diri dan yang tidak mencerminkan harga diri dengan menggunakan media gambar belum memuaskan. Selanjutnya hasil belajar yang dilakukan dalam kegiatan pembelajaran pada siklus I tentang mencerminkan harga diri dan yang tidak mencerminkan 
harga diri dengan menggunakan media gambar baru mencapai 6,4\%. Adapun rincian nilai keberhasilan siswa dapat dirangkum pada tabel sebagai berikut.

Tabel 2. Hasil Belajar Siswa pada Siklus I

\begin{tabular}{cccc}
\hline Nilai & Jumlah Siswa & Frekuensi x Nilai & Persen \\
\hline $\mathbf{1 0}$ & 0 & $0 \times 10=0$ & $0 \%$ \\
$\mathbf{9}$ & 2 & $2 \times 9=18$ & $6 \%$ \\
$\mathbf{8}$ & 5 & $5 \times 8=40$ & $14 \%$ \\
$\mathbf{7}$ & 11 & $11 \times 7=77$ & $31 \%$ \\
$\mathbf{6}$ & 7 & $7 \times 6=42$ & $20 \%$ \\
$\mathbf{5}$ & 7 & $7 \times 5=35$ & $20 \%$ \\
$\leq \mathbf{4}$ & 3 & $3 \times 4=12$ & $9 \%$ \\
Jumlah & 35 & 224 & $100 \%$ \\
Rata-rata & & 6,4 & Belum tuntas \\
\hline
\end{tabular}

Pada tabel tersebut di atas dapat diketahui bahwa rata-rata kelas baru mencapai 6,4 sebanyak 7 orang siswa dengan tingkat ketuntasan belajar mencapai 20\%. Dengan demikian dapat kiranya dikatakan pada siklus I belum berhasil mncapai ketuntasan belajar dan belum memiliki pengaruh yang berarti terhadap prestasi belajar siswa pada kompetensi tersebut. Hal ini diduga kuat oleh faktor perhatian siswa belum terfokus terhadap materi yang diajarkan dan belum mengenanya strategi mengajar dilakukan guru terutama dalam penggunaan media gambar.

Secara klasikal, kemampuan siswa dalam penguasaan materi pembelajaran perilaku mencerminkan perilaku harga diri baru mencapai $64 \%$; banyak siswa yang baru menguasai materi dengan baik $20 \%$, banyak siswa yang cukup menguasai ada $31 \%$ dan sebanyak $49 \%$ siswa yang belum menguasai materi. Untuk lebih jelasnya hasil belajar siswa yaitu: (1) Menjawab soal seluruhnya dengan benar sebanyak 0 siswa; (2) Menjawab soal $90 \%$ dengan benar ada 2 siswa; (3) Menjawab soal $80 \%$ dengan benar ada 5 siswa; (4) Menjawab soal 70 $\%$ dengan benar ada 11 siswa; (5) Menjawab soal $60 \%$ dan $50 \%$ dengan benar ada 7 siswa; (6) Menjawab soal $50 \%$ dengan benar ada 7 siswa; (7) Menjawab soal $40 \%$ dengan benar ada 3 siswa. Dari rincian hasil belajar siswa yang tertera di atas hasil belajar baru mencapai ratarata 6,4. Sedangkan standar nilai di sekolah adalah 6,5. Jadi perolehan hasil belajar siswa siklus I belum mencapai target. Hasil belajar masih rendah, belum sesuai dengan apa yang diharapkan peneliti. Hal ini perlu dilanjutkan ke siklus ke II.

\section{Refleksi}

Hasil dan lembar observasi serta dokumentasi catatan lapangan dianalisis dan dijadikan bahan untuk memperbaiki tindakan yang akan diberikan berikutnya. Adapun kendala yang dihadapi pada siklus pertama adalah penguasaan dan keluwesan guru dalam penggunaan media gambar selama proses pembelajaran perlu ditingkatkan, masih adanya siswa yang bermain-main sewaktu pembelajaran berlangsung atau kurang serius dan suka asyik mengobrol dengan teman sebangkunya, gambar yang dipajang perlu diwarnai agar lebih menarik bagi siswa, informasi yang diberikan kepada siswa mengenai kegiatan yang akan datang agar lebih ditekankan agar siswa lebih siap dengan kegiatan pembelajaran, masih ada beberapa siswa yang tidak mengacuhkan teguran dari gurunya dan bersikap individualisme, gambar yang ditampilkan agar diperbesar lagi ukurannya, dan waktu yang disediakan dalam diskusi agar lebih ditambah. Tindakan yang harus dipertahankan dalam siklus ini untuk siklus selanjutnya adalah guru berperilaku ramah dan bersabar terhadap siswa, media gambar memudahkan siswa untuk memahami konsep pembelajaran, siswa mempunyai semangat belajar yang tinggi, kesenangan belajar karena gambar sangat menarik, keberhasilan dalam kerja kelompok, mereka berani mempresentasikan ke depan kelas. 


\section{Deskripsi Siklus II}

1. Perencanaan

Sebelumnya praktisi mempersiapkan Rencana Pelaksanaan Pembelajaran (RPP), media, gambar, lembar kerja siswa (LKS) dan kunci jawaban LKS yang akan digunakan dalam kegiatan belajar kelompok. Kemudian peneliti sebagai guru mempersiapkakn lembar observasi untuk pengamat guna mengamati jalannya pembelajaran tentang harga diri dengan menggunakan media gambar. Semua persiapan yang telah disiapkan oleh praktisi sebelum pelaksanaan pembelajaran dapat dilihat pada lampiran.

\section{Pelaksanaan}

Penerapan penggunaan media gambar dalam pembelajaran PKn disusun berbentuk Rancangan Pelaksanaan Pembelajaran (RPP). RPP ini disusun 1 kali pertemuan dengan alokasi waktu 2 x 35 menit. Standar kompetensinya adalah memiliki harga diri sebagai individu, selanjutnya kompetensi dasar adalah menampilkan perilaku yang mencerminkan harga diri. Materi pelajaran adalah tentang harga diri. Indikator dalam proses pembelajaran adalah: 1) menjelaskan cara menjaga dan meningkatkan harga diri, 2) menampilkan salah satu perilaku yang mencerminkan harga diri, dan 3) menjelaskan akibat tindakan yang tidak mencerminkan harga diri.

\section{Pengamatan}

Dalam kegiatan ini diperoleh hasil proses pembelajaran pada siklus II lebih meningkat daripada hasil proses pembelajaran pada siklus I. Berdasarkan hasil proses pembelajaran tentang mencerminkan harga diri dan yang tidak mencerminkan harga diri dengan menggunakan media gambar pada siklus II dapat diindikasikan sebagai berikut: 1) kreativitas siswa dalam mengomentari gambar sebanyak 30 orang, 2) motivasi siswa dalam menanggapi komentar teman sebanyak 32 orang, 3) menjawab pertanyaan guru sebanyak 31 orang. Hasil proses pembelajaran dapat dilihat pada tabel di bawah ini.

Tabel 5. Proses Pembelajaran Siswa pada Siklus II

\begin{tabular}{lcc}
\hline \multicolumn{1}{c}{ Aspek yang Diamati } & Jumlah Siswa & Persen \\
\hline Kreativitas siswa dalam mengomentari gambar & 30 & $86 \%$ \\
$\begin{array}{l}\text { Motivasi siswa dalam menanggapi komentar } \\
\text { teman }\end{array}$ & 32 & $92 \%$ \\
Menjawab pertanyaan guru & 31 & $89 \%$ \\
\hline
\end{tabular}

Berdasarkan tabel hasil proses pembelajaran di atas, dapat disimpulkan bahwa proses pembelajaran PKn dengan menggunakan media gambar di kelas III SDN 17 Gunung Pangilun Padang bisa dikatakan sudah menunjukkan peningkatan. Berdasarkan hasil observasi yang dilakukan pengamat dalam kegiatan pembelajaran siklus II ini diketahui motivasi belajar siswa sudah lebih meningkat dan kegiatan pembelajaran dianggap cukup baik, alat peraga yang digunakan cukup variatif. Untuk mengetahui hasil proses pembelajaran siklus II maka diperoleh kreatifitas siswa dalam mengomentari gambar 30 orang, memotivasi siswa dalam menanggapi komentar teman 32 orang dan menjawab pertanyaan guru 31 orang. Adapun hasil tes akhir siklus II yang dilakukan pada akhir pertemuan, maka hasil tes siklus II yang diperoleh sebagai berikut: 
Tabel 6. Hasil Belajar Siswa pada Siklus II

\begin{tabular}{cccc}
\hline Nilai & Jumlah Siswa & Frekuensi x Nilai & Persen \\
\hline $\mathbf{1 0}$ & 3 & $3 \times 10=30$ & $9 \%$ \\
$\mathbf{9}$ & 9 & $9 \times 9=81$ & $26 \%$ \\
$\mathbf{8}$ & 12 & $12 \times 8=96$ & $34 \%$ \\
$\mathbf{7}$ & 7 & $7 \times 7=49$ & $20 \%$ \\
$\mathbf{6}$ & 4 & $4 \times 6=24$ & $11 \%$ \\
$\mathbf{5}$ & - & - & - \\
$\leq \mathbf{4}$ & - & - & - \\
Jumlah & 35 & 280 & $100 \%$ \\
Rata-rata & & 8,0 & \\
\hline
\end{tabular}

Berdasarkan tabel tersebut di atas, diperoleh gambaran bahwa ada 4 orang siswa yang belum mencapai nilai standar yang ditetapkan penelitian yaitu baru dapat mencapai nilai 6 , meskipun apabila dianalisis dari perkembangan nilai pada keempat siswa tersebut sudah mengalami peningkatan. Berdasarkan hasil belajar yang diperoleh pada siklus II dapat dikatakan memuaskan, karena rata-rata hasil belajar sebesar 8,0 yang berarti lebih baik dan tuntas. Untuk mengetahui hasil belajar siswa siklus II yang memperoleh nilai tertinggi yaitu 10 sebanyak 3 orang, nilai 9 sebanyak 9 orang, yang mendapat nilai 8 sebanyak 12 orang, yang mendapat nilai 7 ada 7 orang dan $\leq 6$ sebanyak 4 . Berdasarkan tabel analisis hasil belajar tersebut di atas diketahui bahwa siswa yang mendapatkan nilai 5 sebanyak 0 orang. Untuk menentukan ketuntasan belajar atau mengetahui peningkatan belajar diketahui bahwa rata-rata hasil belajar yang dicapai adalah 8,0 meningkat dari siklus sebelumnya yaitu 6,4 menjadi 8,0 yang berarti ada peningkatan 1,6. Peningkatan tersebut dapat dilihat pada tabel berikut:

Tabel 7. Keberhasilan Siklus II

\begin{tabular}{ccc}
\hline Nilai & Jumlah & Persen \\
\hline$\leq \mathbf{7 0}$ & 4 & $11 \%$ \\
$\geq \mathbf{7 0}$ & 31 & $89 \%$ \\
Jumlah & 35 & $100 \%$ \\
Rata-rata & 8,0 & \\
\hline
\end{tabular}

\section{Refleksi}

Kegiatan refleksi dilakukan secara kolaboratif antara peneliti dan guru kelas pada setiap pembelajaran berakhir. Pada kesempatan ini temuan dan hasil pengamatan peneliti dibahas bersama observer. Refleksi tindakan siklus II ini mencakup refleksi terhadap perencanaan, pelaksanaan, evaluasi dan hasil yang diperoleh oleh siswa. Seluruh rangkaian kegiatan yang dianalisis, dimaknai, di terangkan sampai menyimpulkan semua informasi yang diperoleh selama proses pembelajaran PKn tentang harga diri dengan menggunakan media gambar di kelas III. Hasil belajar di kelas mulai dari awal kegiatan sampai akhir kegiatan melalui perbaikan dari kelemahan yang ditemui pada siklus I dan dilakukan perbaikan hingga pada siklus II sehingga dapat diperoleh kekuatan yang membuat sempurnanya kegiatan proses pembelajaran.

Dari pengamatan observer tidak terdapat permasalahan yang terlalu kompleks. Jalannya proses pembelajaran juga sesuai dengan yang diharapkan karena siswa memenuhi persyaratan sebagai siswa yang memiliki wawasan cemerlang dan suka berpikir kritis untuk selalu ingin tahu dengan perilaku harga diri sedalam-dalamnya. Hasil perolehan dan perhitungan data telah terlampir pada analisis data siklus II. Data proses pembelajaran yang berlangsung pada siklus II menunjukan bahwa materi yang diajarkan teridentifikasi cukup jelas, materi esensial yang dipilih adalah lanjutan dari materi siklus I yaitu perilaku harga diri. Proses pembelajaran sudah berorientasi pada aktivitas kerja dengan menggunakan media gambar. Hasil observasi terhadap siswa selama pembelajaran ternyata menunjukan adanya peningkatan aktivitas siswa 
yang signifikan dibandingkan siklus I baik berupa interaksi sesama rekan sekelompok maupun interaksi kepada guru ketika bertanya. Hal ini disebabkan pada siklus II kondisi siswa sudah lebih baik dan terarah seperti pada siklus I sehingga keadaan menjadi sangat kondusif dan terorganisir.

Pada observasi siklus II menunjukan peningkatan pemahaman siswa terhadap konsep yang dipelajari sudah mulai baik. Kemampuan siswa mengembangkan dan menginterprestasikan materi sudah menggunakan tindakan penalaran dan berpikir kritis sehingga proses belajar mengajar dapat berjalan dengan lancar dan target yang diinginkan dapat tercapai. Antusias siswa tinggi sehingga suasana kelas jadi lebih semarak. Konsentrasi dan semangat siswa lebih meningkat daripada siklus I. Guru lebih memahami dan siap dalam mengajar dan tetap mempertahankan penampilan seperti sebelumnya. Siswa sudah bisa mengembangkan materi yang dipelajari sehingga hal ini dapat meningkatkan prestasi belajar siswa menjadi lebih baik. Dengan adanya media gambar maka dapat menumbuhkan semangat siswa dalam belajar.

\section{PEMBAHASAN}

\section{Siklus I}

Pada bagian ini dilakukan bahasan hasil penelitian yang telah dipaparkan sebelumnya. Pusat bahasannya adalah penggunaan media gambar dalam pembelajaran PKn di kelas III SDN 17 Gunung Pangilun Padang. Berdasarkan hasil penelitian dan pelaksanaan pembelajaran dengan menggunakan media gambar pada pembelajaran PKn di kelas III terungkap bahwa setiap guru harus memiliki Rencana Pelaksanaan Pembelajaran (RPP) yang matang sebelum melaksanakan pembelajaran. Cynthia (dalam E. Mulyasa, 2006) mengemukakan bahwa proses pembelajaran yang dimulai dengan fase pengembangan rencana pelaksanaan pembelajaran, ketika kompetensi dan metodologi telah di dentifikasi, akan membantu guru dalam mengorganisasikan materi standar, serta mengantisipasi peserta didik dan masalah-masalah yang mungkin timbul dalam pembelajaran. Sebaliknya, tanpa rencana pelaksanaan pembelajaran, seorang guru akan mengalami hambatan dalam proses pembelajaran yang dilakukan.

Rencana pelaksanaan pembelajaran adalah penjabaran silabus ke dalam unit satuan kegiatan pembelajaran untuk dilaksanakan di kelas. Rencana pelaksanaan pembelajaran yang memuat berapa indikator yang terkait untuk dilaksanakan dalam atau beberapa kali pertemuan. Perencanaan pembelajaran yang dirancang guru sejalan dengan saran Davis (dalam Hamalik 2001) yang menetapkan bahwa dalam merancang perencanaan pembelajaran berlangsung bertahap-tahap: 1) menetapkan status sistem pengajaran, 2) merumuskan tujuan pengajaran, 3) merencanakan dan melaksanakan evaluasi, 4) mendiskripsikan dan mengaji tugas dan 5) melaksanakan prinsip-prinsip belajar. Berdasarkan data hasil penelitian terungkap bahwa perencanaan yang dirancang guru sesuai dengan langkah-langkah tersebut. Dalam perencanaan terdapat unsur: 1) Standar kompetensi, 2) Kompetensi dasar, 3) Indikator, 4) Tujuan pembelajaran, 5) Materi pembelajaran, 6) Kegiatan belajar mengajar yang terdiri dari metode dan pokok-pokok kegiatan, 7) Alat dan sumber yang terdiri dari alat pelajaran dan sumber bahan, dan 8) Evaluasi yang terdiri prosedur, alat evaluasi dan soal tes. Semua komponen tersebut terdapat dalam semua perencanaan yang ditulis peneliti dalam perencanaan siklus I.

Berdasarkan RPP yang dirumuskan pada siklus I ini, kegiatan pembelajaran yang dilakukan bertujuan untuk menciptakan kondisi yang memungkinkan terjadinya belajar pada diri siswa. Dalam suatu kegiatan pembelajaran, siswa dikatakan telah belajar apabila terjadi proses perubahan perilaku pada diri siswa sebagai hasil dari suatu pengalaman. Pembelajaran dengan menggunakan media gambar memberikan kesempatan kepada siswa untuk belajar, menemukan, mengembangkan fakta, konsep dan prinsip ilmu pengetahuan bagi diri siswa. Berdasarkan catatan hasil pengamatan dan diskusi peneliti dengan guru kelas III, maka penyebab belum suksesnya siklus I ini secara garis besar adalah segi bentuk media sudah dapat menarik perhatian siswa tetapi masih ada kekurangan dari media yaitu pada bagian-bagian tertentu pada media ada yang kurang jelas karena ukurannya kecil. Kemudian dari segi guru atau peneliti yaitu peneliti kurang dalam pengelolaan kelas, peneliti kurang memberikan motivasi atau penguatan kepada siswa, sehingga mengakibatkan siswa kurang semangat dalam belajar. Dari analisis penelitian siklus I nilai rata-rata pembelajaran PKn siswa 
baru mencapai 6,4. Berdasarkan hasil pengamatan siklus I yang diperoleh, maka direncanakan untuk melakukan perbaikan pada pembelajaran berikutnya atau perbaikan selama proses pembelajaran pada siklus II. Pada siklus II nantinya guru harus memperhatikan kekurangankekurangan selama proses pembelajaran pada siklus I dan memperbaikinya pada silus II.

\section{Siklus II}

Rencana pelaksanaan pembelajaran (RPP) pada siklus II ini hampir sama dengan siklus I, namun dalam penggunaan media, pengembangan materi, alat yang digunakan lebih maksimal. Pembelajaran menampilkan perilaku harga diri dengan menggunakan media gambar pada siklus II ini sudah berjalan dengan baik, ini dapat dibuktikan dengan nilai yang diperoleh siswa sudah baik yaitu dengan rata-rata 8,0. Peningkatan hasil belajar siswa dipengaruhi oleh berbagai faktor seperti motivasi, kematangan, hubungan siswa dengan guru, kemampuan verbal, tingkat kebebasan, rasa aman, dan keterampilan guru dalam berkomunikasi. Guru perlu menggunakan media gambar dalam pembelajaran PKn, karena dengan menggunakan media gambar, siswa dapat menemukan sendiri konsep yang dijadikan tujuan oleh peneliti.

Pada pembelajaran yang dilakukan pada siklus II ini, peneliti sudah memberikan kesempatan kepada siswa untuk melakukan langkah pembelajaran dengan menggunakan media gambar yang dipandu dengan panduan pembelajaran menampilkan perilaku harga diri dengan menggunakan media gambar.Dari analisis penelitian siklus II, kemampuan siswa dengan menggunakan media gambar dalam pembelajaran sudah sangat baik. Hasil ini dibuktikan dengan hasil belajar yang diperoleh siswa sudah mencapai rata-rata kelas 8,0. Berdasarkan hasil pengamatan maka pelaksanaan siklus II sudah baik dan guru sudah berhasil menggunakan media gambar untuk meningkatkan hasil belajar siswa pada perilaku yang mencerminkan harga diri dan tidak mencerminkan harga diri di kelas III SDN Gunung Pangilun Padang.

Pada pelaksanaan siklus II ini guru memberikan banyak kesempatan kepada siswa untuk melakukan semua langkah pembelajaran dengan menggunakan media gambar. Pada siklus ini siswa dibawa pada suasana yang baru dan menyenangkan seperti yang dikemukakan oleh Bruner dalam Rokhiyah (1999) bahwa proses belajar mengajar akan berjalan dengan baik dan kreatif jika guru memberikan kesempatan kepada siswa untuk menetukan dan melakukan sesuatu. Oleh karena itu sudah seharusnya guru dalam membelajarkan siswa perlu memperhatikan pembelajaran itu, apakah sesuai dengan kebutuhan dan perkembangan siswa, serta memperhatikan keberhasilan siswa dalam memahami sesuatu dengan cara yang sesuai dengan tingkat kemampuannya, bukan pembelajaran yang hanya disukai guru. Untuk membelajarkan siswa, guru harus menggunakan berbagai macam cara agar pembelajaran dapat bermakna bagi siswa, seperti menggunakan media pembelajaran, menggunakan metode dan pendekatan yang bervariasi, dan menciptakan suasana belajar yang menyenangkan bagi siswa.

\section{KESIMPULAN}

Proses pembelajaran PKn dengan menggunakan media gambar di kelas III SDN 17 Gunung Pangilun Padang lebih memuaskan daripada tidak menggunakan media dalam proses pembelajaran. Hal itu dapat dibuktikan dari kreativitas siswa yang meningkat dari $40 \%$ menjadi $86 \%$, motivasi siswa yang meningkat dari 32\% menjadi $92 \%$ dan aktivitas menjawab pertanyaan guru dari $35 \%$ menjadi 89\%. Hasil belajar PKn siswa kelas III SDN 17 Gunung Pangilun Padang dengan menggunakan media gambar lebih menunjukan peningkatan. Hal ini dapat dilihat dari hasil belajar siklus II lebih tinggi daripada siklus I yaitu dari 6,4 meningkat menjadi 8,0.

\section{SARAN}

Disarankan kepada para pendidik sekolah dasar diharapkan menyiapkan media sebelum kegiatan pembelajaran. Selain itu, kepala sekolah dasar kiranya dapat memberikan perhatian kepada guru terutama dalam penyediaan media dan alat dalam pembelajaran agar hasil belajar siswa dapat ditingkatkan dengan kreativitas dan motivasi siswa dalam belajar dengan menggunakan media gambar. 


\section{DAFTAR RUJUKAN}

Ali, M. (2004). Guru Dalam Proses Belajar Mengajar. Bandung: Sinar Baru Algensindo.

Ariani, Desi. (2006). Pengaruh Penggunaan Media Gambar Dalam Pembelajaran IPS di Sekolah Dasar. Padang : FIP UNP.

Arief, S.Sadiman dkk. (2003). Media Pendidikan. Jakarta: PT Raja Grafindo Persada.

Arikunto, Suharsimi. (2004). Evaluasi Program Pendidikan. Jakarta: PT. Bumi Aksara.

Arsyad, Azhar. (2003). Media Pembelajaran. Jakarta: PT Raja Grafindo Persada.

Aziz, M. dan Ahmad K.D. (1997). Pendidikan Pancasila. Jakarta: Rineka Cipta.

Hamalik, Oemar. (1997). Media Pendidikan. Bandung: Alumni Jakarta: PT Rineka Cipta.

Ritawati, Mahyudin dan Yetty Ariani. 2007. Metodologi Penelitian Tindakan Kelas. Padang: FIP UNP.

Rohani, Ahmad. (1997). Media Intruksional Edukatif. Jakarta: PT Rineka Cipta.

Ruminiati. (2007). Perkembangan Pendidikan Kewarganegaraan SD. Jakarta: Depdiknas.

Sanjaya, Wina. (2006). Strategi Pembelajaran. Jakarta: Kencana Prenada Media Grup.

Sudjana, Nana dan Riva'i Ahmad. (1997). Media Pengajaran. Bandung: CV Sinar Bandung. 